\title{
RESEARCH
}

Open Access

\section{Application of agro-waste-mediated silica nanoparticles to sustainable agriculture}

\author{
Pooja Goswami and Jyoti Mathur ${ }^{*}$
}

\begin{abstract}
Use of green agronomic techniques for plant development and crop protection is essential for environmental sustainability. The current research investigates a more efficient and long-term technique of manufacturing silica nanoparticles $\left(\mathrm{SiO}_{2} \mathrm{NPs}\right.$ ) from agricultural waste (sugarcane bagasse and corn cob). $\mathrm{SiO}_{2} \mathrm{NPs}$ were synthesized by calcinations of waste residues in muffle furnace with varying temperatures $\left(400-1000^{\circ} \mathrm{C}\right) / 2 \mathrm{~h}$ in the present of static air. Field emission scanning electron microscopy (FESEM), Fourier transmission infrared spectroscopy (FTIR), X-ray diffraction (XRD), and energy dispersive X-ray spectroscopy (EDX) were used to characterize $\mathrm{SiO}_{2} \mathrm{NPs}$ and assessed for their antifungal activity simultaneously investigated the effects of various concentrations of produced $\mathrm{SiO}_{2} \mathrm{NPs}$ on Eruca sativa (E. sativa) physiological and biochemical. With $\mathrm{SiO}_{2} \mathrm{NPs}$ treatment at $1000 \mathrm{\mu g} \mathrm{L}^{-1}$ concentration, the seed germination rate was found to be up to $95.5 \%$, and growth characteristics were enhanced compared to control. Accordingly, the ones treated with $\mathrm{SiO}_{2} \mathrm{NPs}$ grew better than the control ones. The treatment of plant with $\mathrm{SiO}_{2} \mathrm{NPs}\left(500 \mu \mathrm{g} \mathrm{L}^{-1}\right)$ increased the protein content by $14.8 \mathrm{mg} \mathrm{g}^{-1}$, and chlorophyll level was also increased by $4.08 \mathrm{mg} \mathrm{g}^{-1}$ in leaves compared to untreated plant. Disc diffusion experiment was conducted to test the efficiency of $\mathrm{SiO}_{2} \mathrm{NPs}_{\text {against Fusarium }}$ oxysporum and Aspergillus niger for antifungal activities. Highest mycelia growth inhibition was obtained with $73.42 \%$ and $58.92 \%$ for F. oxysporum and A. niger, respectively. The result shows that the $\mathrm{SiO}_{2} \mathrm{NPs}$ have a favorable effect on $E$. sativa growth and germination, enhancing plant production which helps to improve the sustainable agriculture farming and acting as a possible antifungal agent against plant pathogenic fungi.
\end{abstract}

Keywords: Agro-waste, Silica nanoparticles, Hydroponic, Eruca sativa

*Correspondence: contact.srivastava@gmail.com

Department of Bioscience and Biotechnology, Banasthali Vidyapith,

Banasthali Tonk 304022, Rajasthan, India 


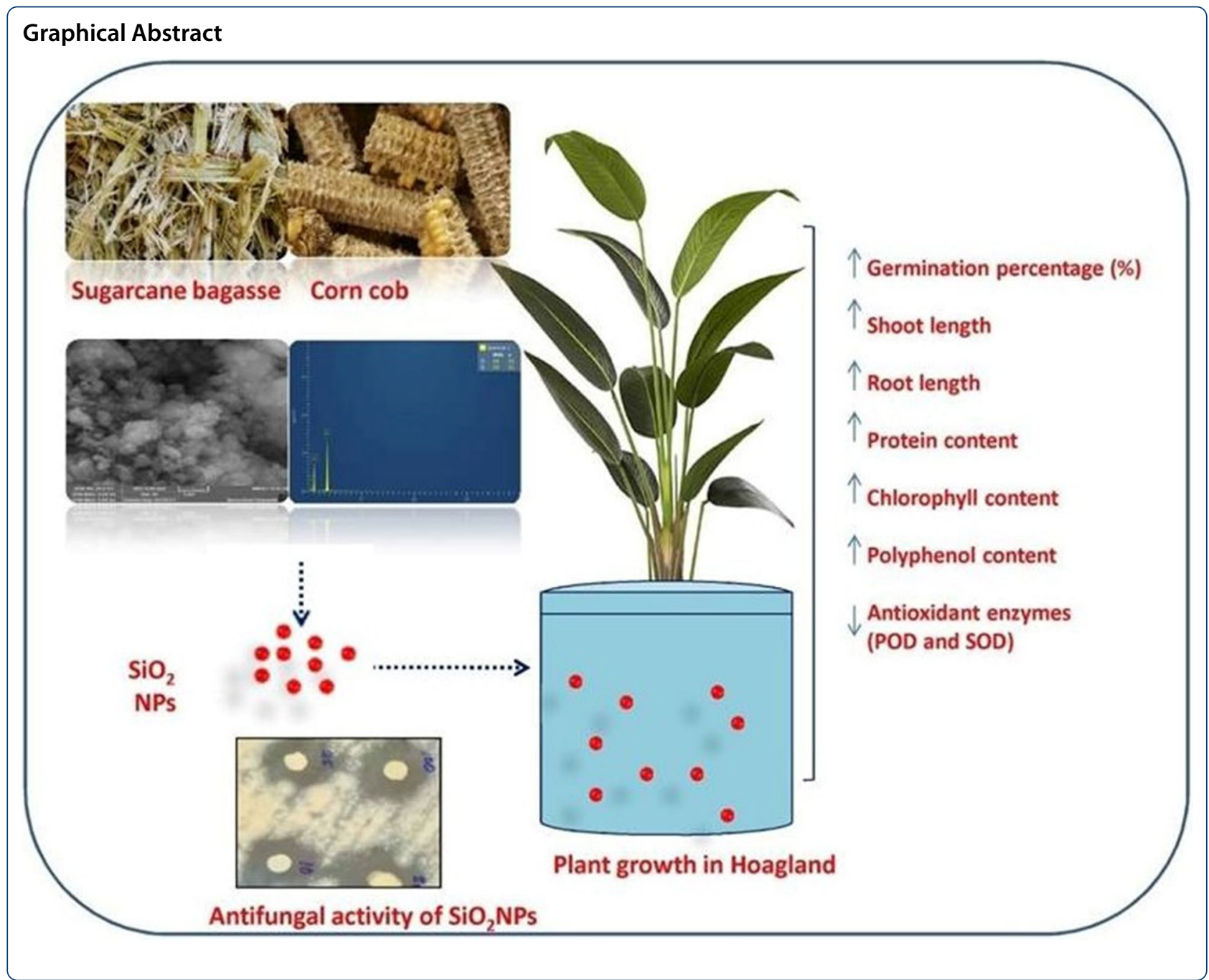

\section{Introduction}

Nanomaterials potential uses are expanding in a variety of industries, including agriculture and biotechnology. Every year, agriculture-based industries generate massive amounts of trash, such as sugarcane bagasse, corncob, rice husk, wheat straw and discharge them into the environment. Dumping and burning of agro-wastes might behave as potent environmental pollutants. These wastes can be exploited as a starting point for the formation of useful nanomaterials. Silica nanoparticles $\left(\mathrm{SiO}_{2} \mathrm{NPs}\right)$ mediated by agro-waste would be a unique concept. NPs and their derivatives are one-of-a-kind not only in terms of treatment approaches, but also in terms of physical and biological characteristics. However, research into the behavior of $\mathrm{SiO}_{2} \mathrm{NPs}$ in agricultural applications is still in its infancy. However, advances in agricultural operations have necessitated the use of $\mathrm{SiO}_{2} \mathrm{NPs}$ to improve stress tolerance and plant growth development (Reynolds et al. 2009). As a result, research have revealed that
$\mathrm{SiO}_{2}$ NPs has a high positive response to biotic and abiotic stress, as well as metal toxicity such as copper, zinc, and iron (Tubana et al. 2016; Mostofa et al. 2021). Earlier, the antifungal activity of $\mathrm{SiO}_{2} \mathrm{NPs}$ was well incorporated in the field of medical science. Fusarium and Aspergillus spp. are highly specialized in infecting crops, according to Aoudou et al. (2011). The application of $\mathrm{SiO}_{2} \mathrm{NPs}$ to maize plants has indicated improved leaf transpiration rates under water stress (Kaya et al. 2006; Gao et al. 2006). Increased sensitivity to biotic and abiotic stresses is caused not only by a lack of necessary plant nutrients, but also by a decrease in silicon content in soil and plants (Ma and Yamaji 2008). $\mathrm{SiO}_{2}$ NPs undergoes polymerization in root tissues prior to transfer and deposition in the shoot sections (Debona et al. 2017). Because of their huge surface area and tiny size, $\mathrm{SiO}_{2}$ NPs are attracting a lot of attention in the agriculture industry. This ensures that $\mathrm{SiO}_{2}$ NPs diffuse well into root tissues (Hafez et al. 2021). $\mathrm{SiO}_{2}$ NPs (less than $20 \mathrm{~nm}$ ) inhibited seed germination 
and growth of rice seedlings, according to Nair et al. (2011); however $\mathrm{SiO}_{2}$ NPs larger than $20 \mathrm{~nm}$ had good impacts on several plant parameters. Similarly, investigations found that tomato seedlings treated with $\mathrm{SiO}_{2} \mathrm{NPs}$ had better seed germination (Siddiqui and Al-Whaibi 2014).

The existing field of nanobiotechnology is at the prime stage of development due to lack of execution of novel techniques in industrial scale and yet to be improved with innovative technologies.

Therefore, the present study investigated the antifungal potency of agro-waste-mediated $\mathrm{SiO}_{2}$ NPs by disc diffusion experiment and broth dilution assay. Comparative studies were also performed to analyze the impacts of these synthesized $\mathrm{SiO}_{2}$ NPs on physiological and biochemical aspects of taramira (Eruca sativa) seedlings (family: Brassicaceae) in terms of germination rate, morphological characteristics, chlorophyll content, protein and antioxidant enzymes. Agro-waste (sugarcane bagasse and corn cob) is more favorable than physical or chemical approaches for the production of $\mathrm{SiO}_{2} \mathrm{NPs}$ since it is readily accessible, cost effective, eco-friendly, and practicable. This research will offer enough data to use $\mathrm{SiO}_{2}$ NPs to improve agricultural productivity.

\section{Material and methods}

\section{Chemicals and materials}

In the current study, analytical grade reagents were employed. Nitroblue tetrazolium (NBT), ethylenediamine tetra acetic acid (EDTA), dithiothreitol (DTT), polyvinylpolypyrrolidone (PVPP), Triton-X, and riboflavin were purchased from Sigma-Aldrich in India. For deionized water, a Millipore milli-Q system was used. Sugarcane bagasse (SB) was taken from the Daurala sugar mill (Uttar Pradesh) for the $\mathrm{SiO}_{2}$ NPs synthesis, while corn cob (CC) was collected from the local market of Jaipur, Rajasthan.

\section{Synthesis of $\mathrm{SiO}_{2} \mathrm{NPs}$}

SB and $\mathrm{CC}$ were cleaned and dried for $2 \mathrm{~h}$ at $110{ }^{\circ} \mathrm{C}$. A $500 \mathrm{~g}$ of dry waste crushed into little crumbs. Waste residues were introduced into a muffle furnace for calcinations at different temperatures varying from 400 to $1000{ }^{\circ} \mathrm{C}$ at an interval of $200{ }^{\circ} \mathrm{C}$ for $2 \mathrm{~h}$ soaking time in static air. About $10 \mathrm{~g}$ of the resultant ash was agitated in $60 \mathrm{~mL}$ of a $1 \mathrm{~N} \mathrm{NaOH}$ (sodium hydroxide) aqueous solution at $80{ }^{\circ} \mathrm{C}$ to dissolve silica and form sodium silicates $\left(\mathrm{Na}_{2} \mathrm{SiO}_{3}\right)$. The clear solution was allowed to cool at room temperature, and the $\mathrm{pH}$ was maintained at 7 by applying $1 \mathrm{~N} \mathrm{HCl}$ at constant stirring and then incubated for $12 \mathrm{~h}$ to commence gel formation. The synthesized gel was desiccated for $24 \mathrm{~h}$ at $80{ }^{\circ} \mathrm{C}$ to obtain xerogel (Fig. 1). To produce silica powder, the obtained xerogel was dried at $80^{\circ} \mathrm{C}$. (Sarangi et al. 2011; Chanadee and Chaiyarat 2016; Sethy et al. 2019).

\section{Characterization of $\mathrm{SiO}_{2} \mathrm{NPs}$}

Various analytical methods were used to identify and validate the synthesized $\mathrm{SiO}_{2}$ NPs powder. Field emission scanning electron microscopy (FESEM) was used to examine the morphology of $\mathrm{SiO}_{2}$ NPs (model: MIRA3 TESCAN). Prior to FESEM, the samples were sputtered coated with a very thin layer of gold $(\mathrm{Au})$. The elemental configuration of $\mathrm{SiO}_{2} \mathrm{NPs}$ was determined using energy dispersive X-ray spectroscopy (EDX) associated with the FESEM. Aside from that, the crystalline structure of $\mathrm{SiO}_{2}$ NPs was investigated using X-ray diffraction (XRD), patterns (Bruker D8 Discover X-ray Diffraction). A small quantity of small (1 wt \%) was scrupulously mixed with potassium bromide ( $\mathrm{KBr}$ ) pellet (FTIR grade) and a disc was prepared. Thereafter prepared pellet was measured through FTIR spectroscope (Bruker FTIR) have in the wave number region of $4000-400 \mathrm{~cm}^{-1}$ (Kumari and Khan 2017).

\section{Plant material}

Sri Karan Narendra Agriculture University Jobner, Rajasthan, provided E. sativa seeds. The seeds were surface sterilized in a $10 \%$ sodium hypochlorite $(\mathrm{NaClO})$ solution for $10 \mathrm{~min}$ before being germinated in petri plate (50 seeds/plate) with a double layer of filter paper.

\section{Hydroponic cultivation}

Hoagland solution composed of multiple salts to provide a vital nutritional element. It is prepared by combining the macronutrients $\left(\mathrm{g} \mathrm{L}^{-1}\right)$ such as $\mathrm{MgSO}_{4} \cdot 7 \mathrm{H}_{2} \mathrm{O}, \mathrm{KNO}_{3}$, $\mathrm{NH}_{4} \mathrm{NO}_{3}, \mathrm{KH}_{2} \mathrm{PO}_{4}, \mathrm{H}_{3} \mathrm{BO}_{4}, \mathrm{MnSO}_{4} \cdot 4 \mathrm{H}_{2} \mathrm{O}, \mathrm{CaCl}_{2} \cdot 2 \mathrm{H}_{2} \mathrm{O}$ and micronutrients as $\mathrm{ZnSO}_{4} \cdot 7 \mathrm{H}_{2} \mathrm{O}, \mathrm{KI}, \mathrm{CuSO}_{4} \cdot 5 \mathrm{H}_{2} \mathrm{O}$, $\mathrm{FeSO}_{4} \cdot 7 \mathrm{H}_{2} \mathrm{O}, \mathrm{Na}_{2}$ EDTA and $\mathrm{Na}_{2} \mathrm{MoO}_{4} \cdot 2 \mathrm{H}_{2} \mathrm{O}$. The entire investigation was carried out in a plant growth chamber under controlled conditions (photoperiod of $12 \mathrm{~h}$ at temperature $26{ }^{\circ} \mathrm{C}( \pm 2)$ and humidity $21 \%( \pm 2)$ and arranged as completely randomized block designs in replicates.

\section{Impact of $\mathrm{SiO}_{2} \mathrm{NPs}$ on E. sativa}

The effects of $\mathrm{SiO}_{2} \mathrm{NPs}$ on $E$. sativa have been studied in terms of seed germination, physiological and biochemical properties. For the investigation, four different concentrations of $\mathrm{SiO}_{2}$ NPs were used: 100, 250, 500, and $1000 \mu \mathrm{g} \mathrm{L}^{-1}$ (Singh et al. 2015). The NPs suspension for treatment was sonicated for $30 \mathrm{~min}$ to obtain homogenous mixture. Surface sterilized 50 seeds were placed in their respective Petri dishes, and then a suspension of $\mathrm{SiO}_{2}$ NPs at each concentration was added to each Petri dish. Petri dishes were kept in the dark with regulated 


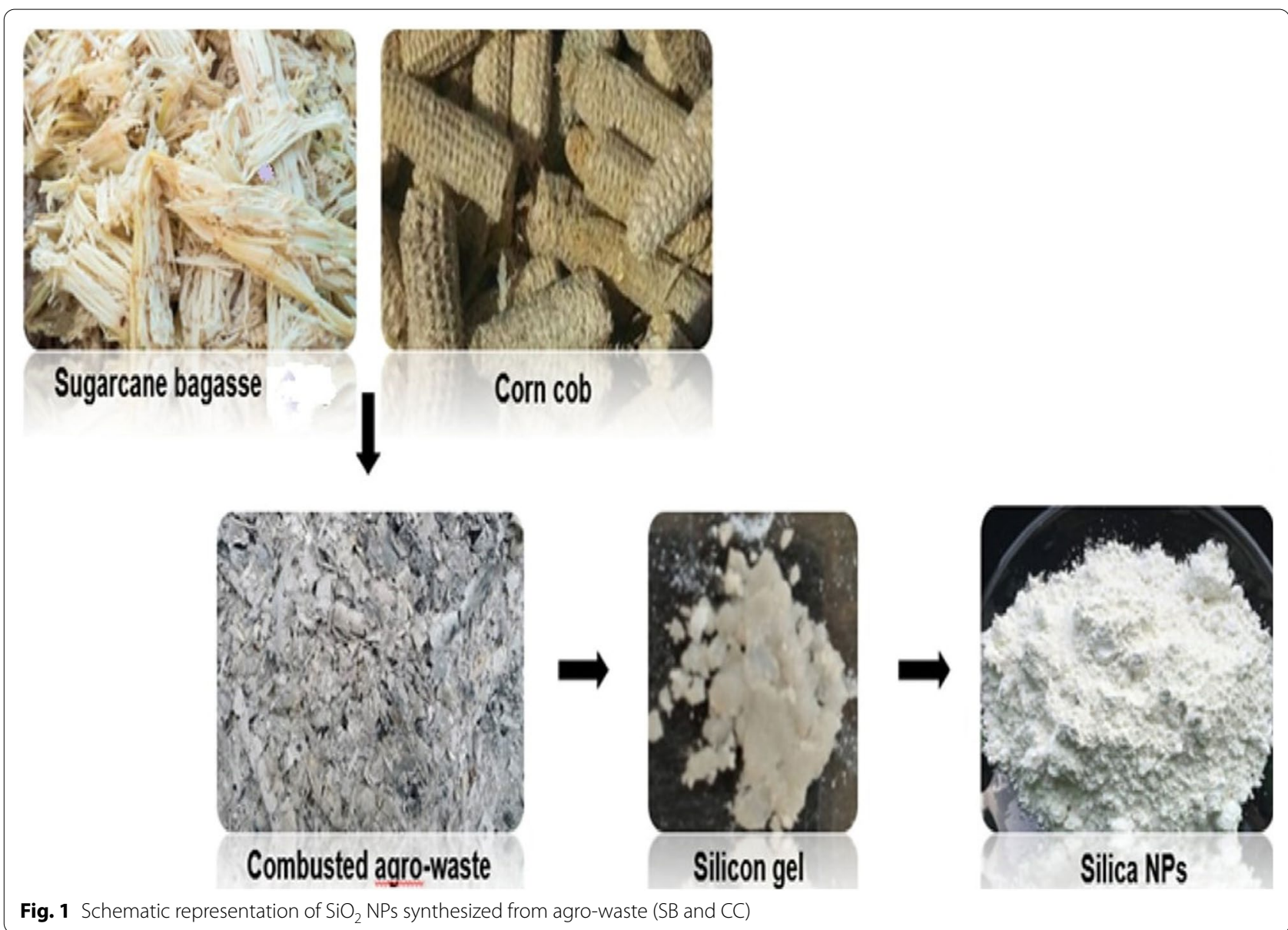

conditions for germination. Firstly, the germination rate was estimated based on the number of seeds germinated, and seeds with a root tip of $1 \mathrm{~mm}$ or greater were considered germinated. Root-shoot length $(\mathrm{cm})$ and biochemical assays were carried out at 3,6 , and 9 days following seed germination.

\section{Polyphenol analysis}

The polyphenol content was determined using the Bray and Thorpe (1954) method. A $0.1 \mathrm{~g}$ plant sample was extracted in $75 \%$ methanol. After adding $25 \%$ sodium carbonate, the absorbance was measured at $725 \mathrm{~nm}$ with a spectrophotometer.

\section{Determination of chlorophyll content}

Li et al. (2016) demonstrated a technique for quantifying chlorophyll a and chlorophyll $b$ in a leaf sample at 3, 6, and 9 days intervals. Seedlings were homogenized with $80 \%$ acetone and incubated overnight. The amount of chlorophyll in the sample was calculated as follows:

$$
\begin{aligned}
& \operatorname{Chl~a}(\mathrm{mg} / \mathrm{L})=12.72\left(\mathrm{~A}_{663}\right)-2.59\left(\mathrm{~A}_{645}\right), \\
& \operatorname{Chl~b}(\mathrm{mg} / \mathrm{L})=22.88\left(\mathrm{~A}_{645}\right)-4.67\left(\mathrm{~A}_{663}\right), \\
& \text { Total chlorophyll content }(\mathrm{mg} / \mathrm{L})=\mathrm{Chl} \mathrm{a}+\mathrm{Chl} \mathrm{b} .
\end{aligned}
$$

\section{Total protein}

Total protein was calculated using the Bradford (1976) method at different concentration and time frames. This was done by mixing $100 \mu \mathrm{L}$ of enzyme extract with $1 \mathrm{~mL}$ of Bradford solution and measuring absorbance at $595 \mathrm{~nm}$.

\section{Antioxidant activity}

The plant's antioxidant potential was determined by monitoring the activity of various enzymes such as superoxide dismutase and peroxidase. Leaf samples $(2.0 \mathrm{~g})$ from non-treated and treated seedlings were rinsed and extracted in $10 \mathrm{~mL}$ extraction buffer $(50 \mathrm{mM}$ phosphate 
buffer (pH 7.0) containing $1 \mathrm{mM}$ EDTA, $3 \mathrm{mM}$ DTT, $5 \% \mathrm{w} / \mathrm{v}$ PVPP, $0.05 \%$ Triton-X). The crude extract was filtered using Whatman filter paper and centrifuged at $13,000 \mathrm{rpm}$ for $30 \mathrm{~min}$ at $4{ }^{\circ} \mathrm{C}$.

Peroxidase activity was measured using the method described by Güneş et al. (2019). $3 \mathrm{~mL}$ of solution comprising $0.5 \mathrm{~mL}$ of guaiacol solution in $0.1 \mathrm{~mL}$ of $\mathrm{pH} 7.0$ sodium phosphate buffer, $0.3 \mathrm{~mL}$ of hydrogen peroxide, and $0.1 \mathrm{~mL}$ of enzyme extract were mixed for this. Peroxidase activity was measured using a spectrophotometer at $436 \mathrm{~nm}$ every $30 \mathrm{~s}$ for up to $3 \mathrm{~min}$. The extinction coefficient $\left(26.6 \mathrm{mM}^{-1} \mathrm{~cm}^{-1}\right)$ of guaiacol at $436 \mathrm{~nm}$ was used to calculate activity.

NBT in the presence of riboflavin was used to assess superoxide dismutase activity (Güneş et al. 2019). After mixing $50 \mu \mathrm{L}$ enzymes extract with $1 \mathrm{~mL}$ NBT $(50 \mathrm{M})$, $500 \mu \mathrm{L}$ methionine $(13 \mathrm{mM}), 1 \mathrm{~mL}$ riboflavin $(1.3 \mathrm{M})$, $950 \mu \mathrm{L}(50 \mathrm{mM})$ phosphate buffer, and $500 \mu \mathrm{L}$ EDTA (75 mM), the absorbance at $560 \mathrm{~nm}$ was measured.

\section{Microscopic analysis}

The presence of $\mathrm{SiO}_{2}$ NPs in root, shoot, and leaf tissues was confirmed using a FESEM associated with EDX. The plant tissues were fixed in a $0.5 \mathrm{M}$ phosphate buffer containing $2.5 \%$ glutaraldehyde, left overnight, and then dehydrated with a series of alcohol concentrations (Kumari and Khan 2018). Light microscopy was used to investigate plant tissues initially, and then SEM was used to examine them further. Aside from that, the existence of $\mathrm{SiO}_{2} \mathrm{NPs}$ in root, shoot, and leaf tissues was confirmed by EDX analysis.

\section{Media for testing fungus and culture conditions}

Strains of Fusarium oxysporum and Aspergillus niger were procured from MTCC, Chandigarh. Each fungal strain was sub-cultured at $27^{\circ} \mathrm{C}$ in potato dextrose agar (Czerwinski and Szparaga 2015).

\section{Disc diffusion assay}

Disc diffusion test was performed to evaluate the antifungal activity as described (Dhabalia et al. 2020). Sterile 6-mm disks were impregnated in the agar plates. Different concentrations of $\mathrm{SiO}_{2}$ NPs were pipetted onto sterile disks. A standard disk of Manocozeb was used as positive control for this study. Plates were then incubated at $30{ }^{\circ} \mathrm{C}$ for 24-48 h until a clear zone of inhibition was formed. The diameter of these zones was measured. Each test was conducted in triplicates to ensure reproducibility.

\section{Minimum inhibitory concentration (MIC)}

MIC assay was carried out using the dilution method with slight modifications. $100 \mu \mathrm{L}$ of $\mathrm{SiO}_{2}$ NPs of known concentration produced throughout sampling period were transferred into 96-well microtiter plates containing $100 \mu \mathrm{L}$ of potato dextrose broth for fungal assay. Dilutions were performed by the twofold serial dilution method. Later, $100 \mu \mathrm{L}$ of tested microorganisms were inoculated to all wells and the microtiter plates were incubated at $27^{\circ} \mathrm{C}$ $(48 \mathrm{~h})$ for fungi. The minimum inhibitory concentration was determined as the lowest concentration of $\mathrm{SiO}_{2} \mathrm{NPs}$ that inhibits the growth of microorganism (Basha and Ulaganathan 2002; Chan and Don 2012).

\section{Statistical analysis}

The results were determined using the analysis of variance (ANOVA) test. Individual bars in the data represent the mean standard deviation of three replicates, followed by a ':' signifying that the means were significantly different $(p \leq 0.05)$ using Tukey's test.

\section{Results and discussion} $\mathrm{SiO}_{2} \mathrm{NPs}$ characterization

FESEM was used to examine the surface morphology of synthesized $\mathrm{SiO}_{2} \mathrm{NPs}$ (Fig. 2a). The majority of NPs were found to be in a nano-agglomerated form with irregular $\mathrm{SiO}_{2}$ NPs shape. The EDX elemental spectrum revealed the presence of $\mathrm{Si}(43.84 \%), \mathrm{O}(24.2 \%)$ and $\mathrm{C}(17.23 \%)$ in the component composition (Fig. 2b). The XRD pattern of $\mathrm{SiO}_{2} \mathrm{NPs}$ is shown in Fig. 2c; strong diffraction peaks of $\mathrm{SiO}_{2} \mathrm{NPs}$ were observed at $2 \theta=36.01^{\circ}, 32.11^{\circ}, 46.10^{\circ}$ and $57.13^{\circ}$. The diffraction peaks reported were similar to Suriyaprabha et al. 2012, and Chanadee and Chaiyarat (2016) which confirmed the crystallographic structure of $\mathrm{SiO}_{2}$ NPs. The Debye-Scherrer equation was used to calculate the average size of $\mathrm{SiO}_{2} \mathrm{NPs}$ (Yew et al. 2016).

Debye-Scherrer equation is shown as:

$$
D=k \lambda / \beta_{\mathrm{hkl}} \cos \theta_{\mathrm{hkl}},
$$

where $D$ is the crystallite size, $\lambda$ is the $\mathrm{X}$-ray wavelength of radiation for Cu Ká $(0.154 \mathrm{~nm}), \beta_{\mathrm{hkl}}$ is the full-width at half-maximum (FWHM), $k$ is Scherrer constant (0.9) and $\theta_{\mathrm{hkl}}$ is the diffraction angle. The average crystallite size of $\mathrm{SiO}_{2} \mathrm{NPs}$ was $17.23 \mathrm{~nm}$.

The chemical composition and functional groups of the produced $\mathrm{SiO}_{2}$ NPs were investigated using a FTIR spectrum. The $1073 \mathrm{~cm}^{-1}$ peak corresponds to the asymmetric stretching vibration and shear bands of $\mathrm{Si}-\mathrm{O}-\mathrm{Si}$ bonds. The symmetric stretching vibration of $\mathrm{Si}-\mathrm{O}$ bonds is represented by the $800 \mathrm{~cm}^{-1}$ peak band (Palanivelu et al. 2014). The vibrational modifications of the silica gel network were disclosed by the peaks detected between 1090 and $799 \mathrm{~cm}^{-1}$ as evident at $1111.39 \mathrm{~cm}^{-1}$. Aside from that, a band at $1645 \mathrm{~cm}^{-1}$ was discovered, which matched to the adsorption of silanol $\mathrm{OH}$ groups (Fig. 2d) (Palanivelu et al. 2014). 


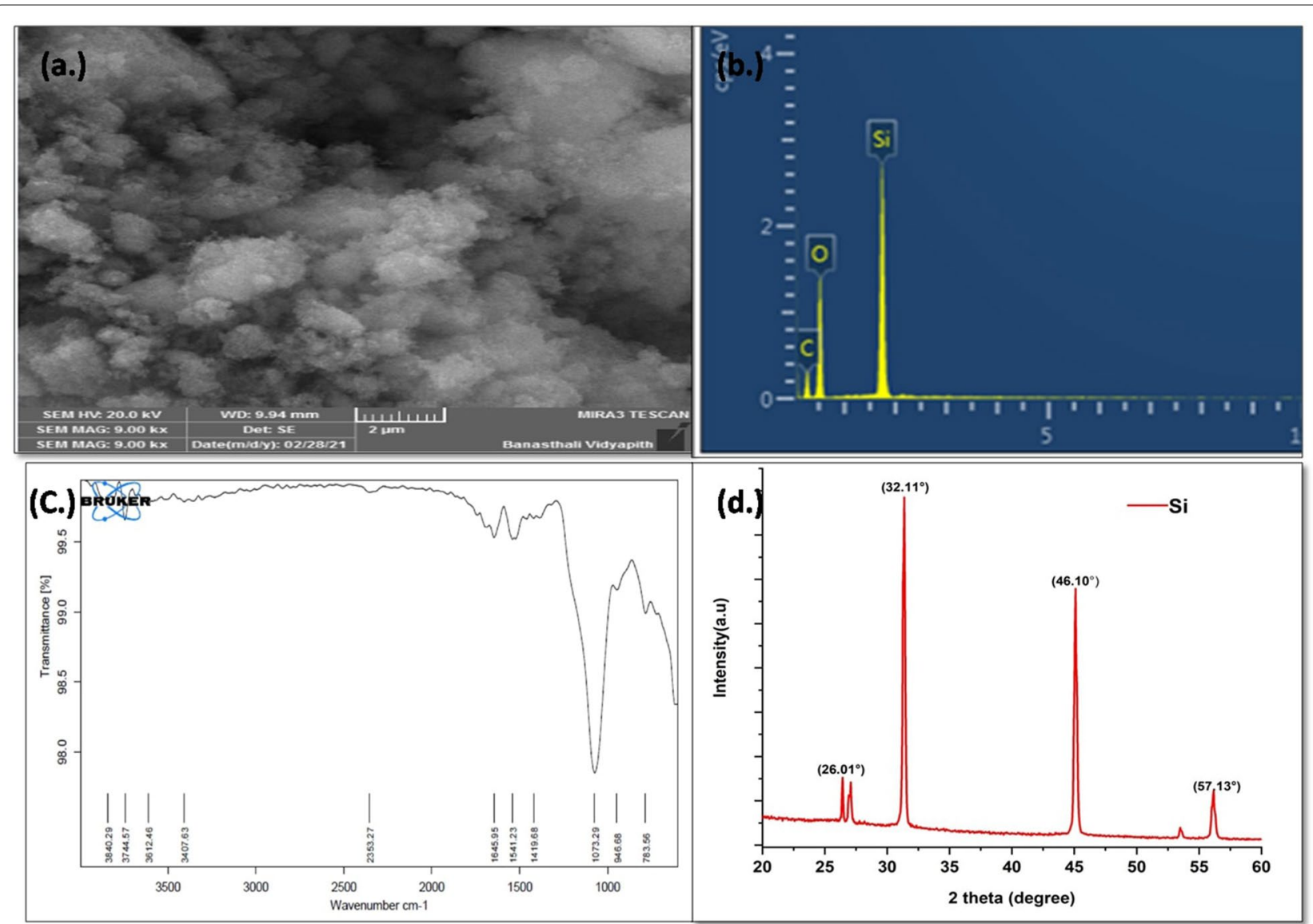

Fig. 2 a-d shows characterization of synthesized $\mathrm{SiO}_{2} \mathrm{NPS}$. a FESEM, b EDX spectrum, c FTIR, and $\mathbf{d}$ XRD pattern

\section{Effect of $\mathrm{SiO}_{2} \mathrm{NPs}$ on E. sativa}

The effects of $\mathrm{SiO}_{2}$ NPs on the majority of the evaluated morphological characteristics in E. sativa seedlings were favorable (Fig. 3a-d). Seed germination was measured for the observation by monitoring the radical presence. Control seedlings were those that had not been treated with $\mathrm{SiO}_{2} \mathrm{NPs}$. All plants treated with $\mathrm{SiO}_{2} \mathrm{NPs}$ had significantly increased germination, shoot and root lengths. After 9 days of treatment with $1000 \mu \mathrm{g} \mathrm{L}^{-1} \mathrm{SiO}_{2} \mathrm{NPs}$, the longest shoot length measured was $6.3 \mathrm{~cm}$, while the shortest shoot length measured was $5.5 \mathrm{~cm}$ in the control (Fig. 3c). Simultaneously, the maximum root length at $1000 \mu \mathrm{g} \mathrm{L}^{-1} \mathrm{SiO}_{2} \mathrm{NPs}$ treatment was $6.6 \mathrm{~cm}$, whereas the lowest root length in control seedlings was $6.3 \mathrm{~cm}$ (Fig. 3d). Overall, the results revealed that root and shoot length were somewhat increased at lower concentrations such as $250 \mu \mathrm{g} \mathrm{L}^{-1}$ and $500 \mu \mathrm{g} \mathrm{L}^{-1}$ and significantly increased at higher concentrations $\left(1000 \mu \mathrm{g} \mathrm{L}{ }^{-1}\right)$. Similar findings were obtained for the treatment with $\mathrm{SiO}_{2} \mathrm{NPs}$, which improved the root-shoot length and growth of cucumber seedlings, however a minor drop was noted after a certain concentration. Maximum root-shoot lengths of 6.51 and $5.10 \mathrm{~cm}$ were recorded at $200 \mu \mathrm{g} \mathrm{L}^{-1} \mathrm{SiO}_{2}$ NPs concentrations (Alsaeedi et al. 2019). The observations made above are consistent with the findings of Nair et al. (2011). This analysis revealed that using FITC-labeled $\mathrm{SiO}_{2} \mathrm{NPs}$ enhanced rice seedling germination. As a result, based on the outcome of $\mathrm{SiO}_{2}$ NPs treatment, we may imagine their direct and indirect engagement in plant growth (Fig. 3a-b) via an increase in seed germination qualities.

\section{Polyphenol content}

Phenols are important defense compounds that protect plants from a variety of stresses because they absorb and deactivate free radicals and decompose peroxides (Shah et al. 2010). The effect of $\mathrm{SiO}_{2}$ NPs on the polyphenol content of treated $E$. sativa seedlings is demonstrated (Fig. 4b). The treatment of varied concentrations of $\mathrm{SiO}_{2} \mathrm{NPs}$ enhanced the polyphenol content linearly. At 9 days intervals, the highest polyphenol content was recorded at $1000 \mu \mathrm{g} \mathrm{L}^{-1} \mathrm{SiO}_{2} \mathrm{NPs}$ therapy while the lowest was reported at $100 \mu \mathrm{g} \mathrm{L}^{-1} \mathrm{SiO}_{2}$ NPs treatment. Similarly, $\mathrm{SiO}_{2}$ NPs treatments boosted the accumulation 


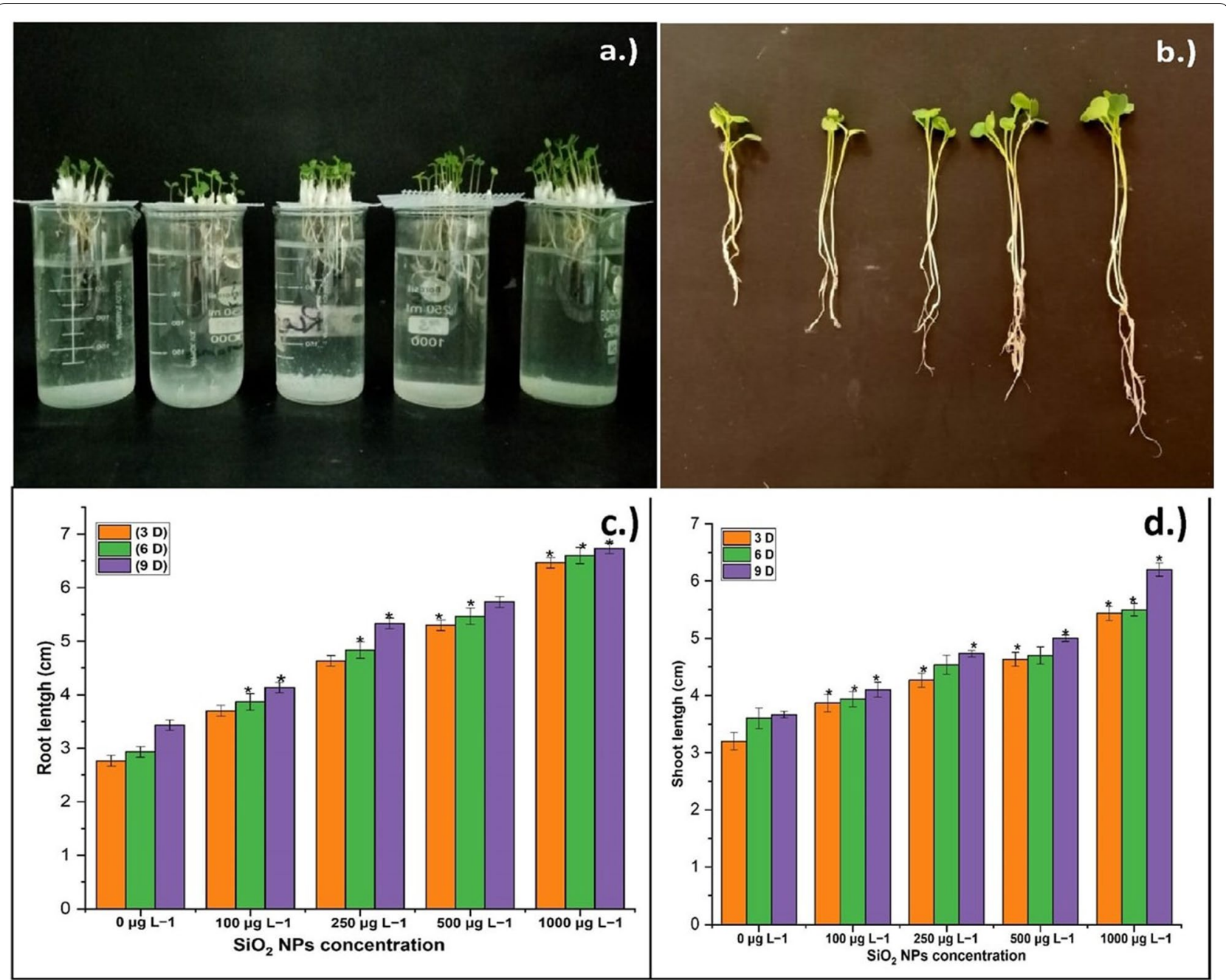

Fig. 3 Effect of $\mathrm{SiO}_{2}$ NPs on E. sativa plant $\mathbf{a}$ and $\mathbf{c}$ root length and $\mathbf{b}$ and $\mathbf{d}$ shoot length at 9 days interval at $100-1000 \mu \mathrm{L} \mathrm{L}^{-1}$ concentration

of phenolic compounds in leaf epidermis compared to untreated leaves. The mechanism of $\mathrm{SiO}_{2} \mathrm{NPs}$ induced phenols may be due to the accumulation of insoluble silica NPs in the epidermis, which induces the enrichment of constitutional phenols in epidermal cells due to their super high adsorption surface (Li et al. 2004).

\section{Determination of chlorophyll and protein content}

Leaves were obtained from treated and control pots, revealing that the chlorophyll a and $\mathrm{b}$ contents increased considerably with increasing $\mathrm{SiO}_{2} \mathrm{NPs}$ concentrations and time intervals (Fig. 5a). Chlorophyll a, b, and total content were found to be highest at $1000 \mu \mathrm{g} \mathrm{L}{ }^{-1} \mathrm{SiO}_{2} \mathrm{NPs}$ concentration and lowest at $100 \mu \mathrm{g} \mathrm{L}^{-1} \mathrm{SiO}_{2}$ NPs concentration. El-Serafy (2019) observed comparable results in his study. Sun et al. (2016) found that mesoporous $\mathrm{SiO}_{2}$ NPs enhanced chlorophyll a, b, and total concentrations, which supported these findings. The results showed an increase in total protein content at 3,6, and 9 days for all $\mathrm{SiO}_{2}$ NPs treatments $\left(100,250,500\right.$, and $\left.1000 \mu \mathrm{g} \mathrm{L}^{-1}\right)$. The reported total protein content with $100 \mu \mathrm{g} \mathrm{L}^{-1}$ treatment, on the other hand, revealed no significant variation as compared to control pots (Fig. 5b). In comparison to 100, 250, and $1000 \mu \mathrm{g} \mathrm{L}^{-1} \mathrm{SiO}_{2}$ NPs treatments, $500 \mu \mathrm{g} \mathrm{L}^{-1}$ $\mathrm{SiO}_{2}$ NPs treatment yielded the highest protein content. Protein content was reduced at the maximum $\mathrm{SiO}_{2} \mathrm{NPs}$ concentration of $1000 \mu \mathrm{g} \mathrm{L}{ }^{-1}$, demonstrating the harmful effect of $\mathrm{SiO}_{2} \mathrm{NPs}$ over a specific concentration. Sun et al. (2016) showed similar results of protein content increase up to a specific threshold. 

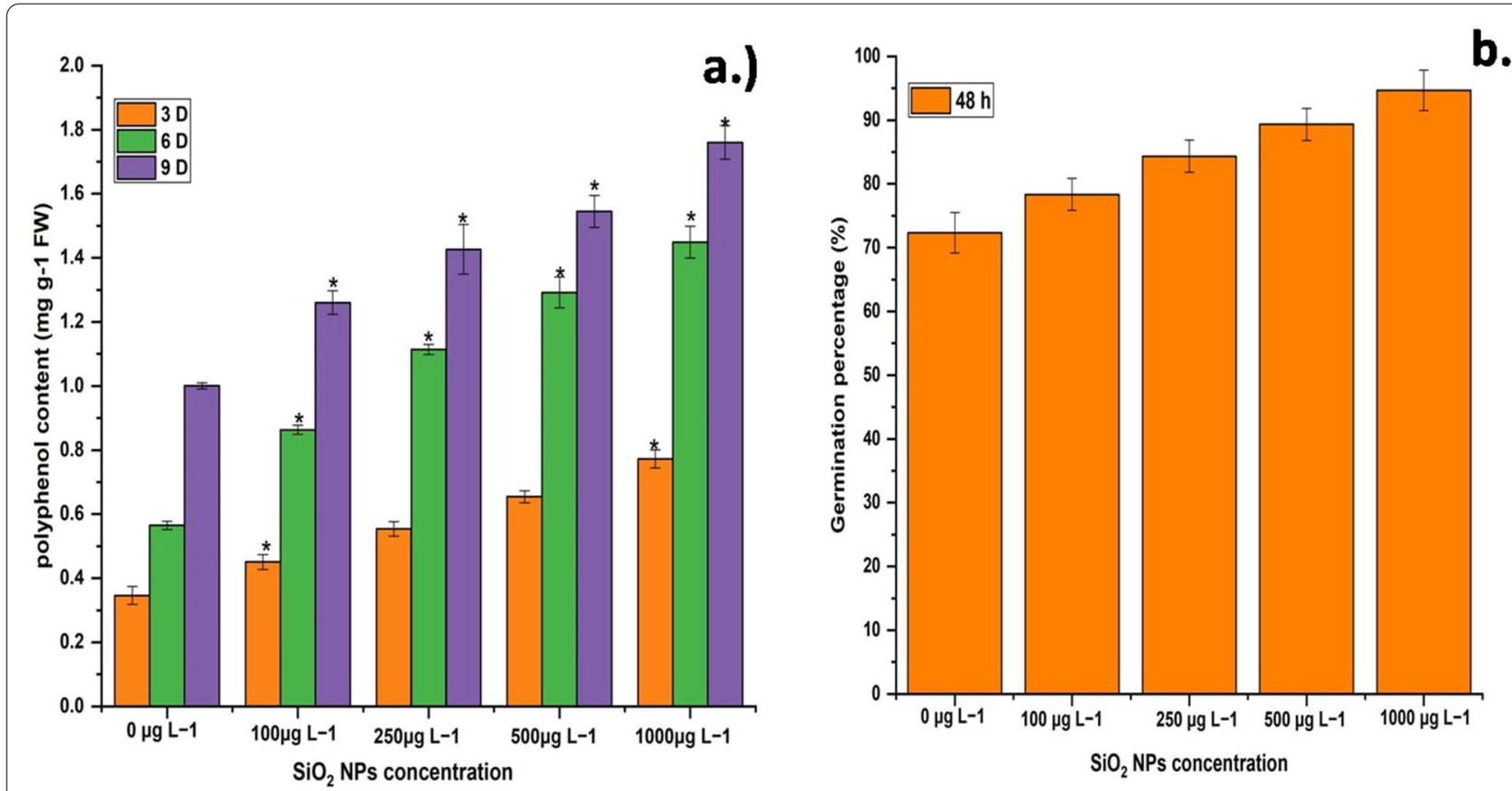

Fig. 4 Effect of different concentrations of $\mathrm{SiO}_{2}$ NPs on E. sativa a germination percentage at $48 \mathrm{~h}$ with concentration 100, 250, 500 and $1000 \mu \mathrm{g} \mathrm{L}-1$ of $\mathrm{SiO}_{2} \mathrm{NPs}$ and $\mathbf{b}$ polyphenol content with same treatment

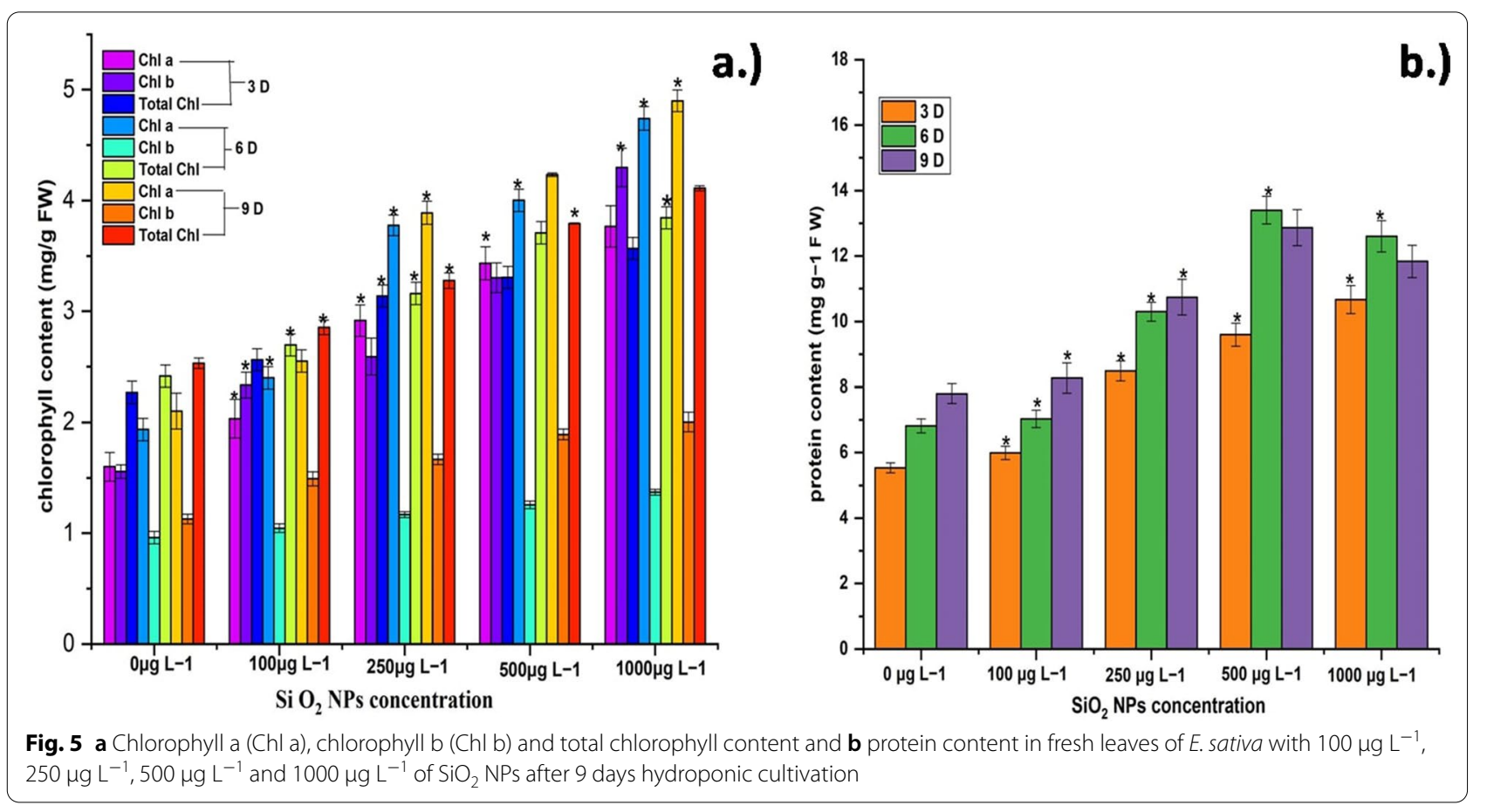

\section{Impact on oxidative stress}

Under oxidative stress, antioxidant enzymes and metabolites exert a significant control on the development of reactive oxygen species (ROS) and their fatal effects.
The antioxidant capacity of the seedlings increased as the amounts of $\mathrm{SiO}_{2}$ NPs increased, as measured by the activity of antioxidant enzymes. In contrast to earlier research, the activity of both antioxidant enzymes, 

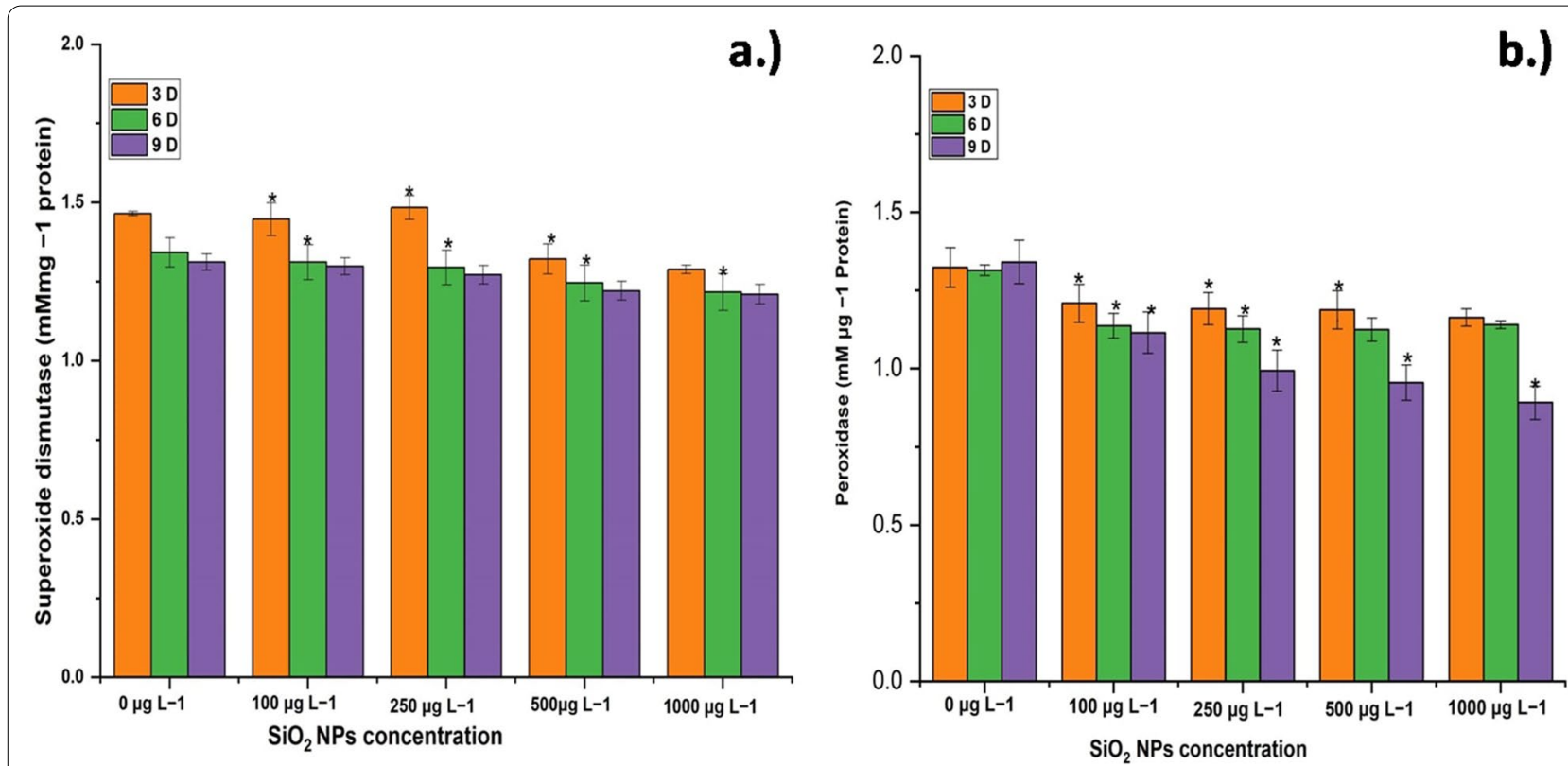

Fig. 6 Antioxidant activity a peroxidase and $\mathbf{b}$ superoxide dismutase of E. sativa with 100, 250, 500 and $1000 \mu g \mathrm{~L}^{-1}$ of $\mathrm{SiO}_{2} \mathrm{NPs}_{\text {after }} 9$ days

peroxidase and superoxide dismutase, was lowered with increasing $\mathrm{SiO}_{2} \mathrm{NPs}$ treatments, even when the treatment method was the same. Peroxidase activity reduced when $\mathrm{SiO}_{2}$ NPs treatments increased, according to spectrophotometric analysis (Fig. 6a). All $\mathrm{SiO}_{2} \mathrm{NPs}$ treatments $\left(100-1000 \mu \mathrm{g} \mathrm{L}^{-1}\right)$ reduced peroxidase activity. The activity of superoxide dismutase and peroxidase reduced as the concentration of $\mathrm{SiO}_{2}$ NPs increased from 100 to $1000 \mu \mathrm{g} \mathrm{L}^{-1}$ (Fig. 6b). This reduction might be due to the better growing medium and nutrition given by $\mathrm{SiO}_{2}$ NPs. Cucumber seedlings treated with $\mathrm{SiO}_{2}$ NPs showed a reduction in the quantity of ROS species (i.e., $\mathrm{H}_{2} \mathrm{O}_{2}$ ) in a comparable research (Alsaeedi et al. 2019). A linear reduction in peroxidase activity was found as a result of increasing the dosage of applied $\mathrm{SiO}_{2} \mathrm{NPs}$. The soil treatment (S 200) produced the maximum peroxidase activity, whereas the foliar treatment of $200 \mathrm{mg} \mathrm{L}^{-1}$ produced the lowest peroxidase activity when compared to the soil treatment of the same dose (Attia and Elhawat 2021).

\section{Microscopic studies}

FESEM images of transverse sections (T.S.) of shoot and root tissues at $1000 \mu \mathrm{g} \mathrm{L}{ }^{-1}$ revealed $\mathrm{SiO}_{2}$ NPs uptake and accumulation in leaf, shoot, and root tissues of treated seedlings (Fig. 7). The existence of NPs was confirmed after 9 days of $\mathrm{SiO}_{2} \mathrm{NPs}$ therapy (Fig. 7c and e). The presence of $\mathrm{SiO}_{2} \mathrm{NPs}$ was also visible in FESEM images of leaf tissues (Fig. 7a). The presence of $\mathrm{SiO}_{2}$ NPs peaks in leaf, shoot, and root tissues was confirmed by EDX analysis for further validation (Fig. 7b, d, f).

\section{Antifungal activity}

The disc diffusion experiment was used to assess the antifungal efficacy of $\mathrm{SiO}_{2} \mathrm{NPs}$ against $F$. oxysporum and $A$. niger mycelia on potato dextrose agar plates. A control plate with no $\mathrm{SiO}_{2} \mathrm{NPs}$ was maintained independently for both fungal strains. Fusarium oxysporum and A. niger were both inhibited by $\mathrm{SiO}_{2}$ NPs produced from agrowaste (SB and $\mathrm{CC}$ ), but no zone of inhibition was identified in control plates. At $1000 \mu \mathrm{g} \mathrm{SiO}_{2} \mathrm{NPs}_{\text {concentration, }}$ the maximum percent inhibition reported in $F$. oxysporum and $A$. niger was $73.42 \pm 1.14$ and $58.92 \pm 3.49$, respectively (Table 1 ). The minimum inhibitory concentrations for $F$. oxysporum and $A$. niger were 3.1 and $6.3 \mu \mathrm{g} \mathrm{mL} \mathrm{m}^{-1}$, respectively. Similarly, higher antifungal effectiveness of mesoporous $\mathrm{SiO}_{2} \mathrm{NPs}$ against Alternaria solani in tomato plants has been found (Derbalah et al. 2018). The study demonstrated the highest inhibitory effectiveness of about $95 \%$ for both fungus $F$. oxysporum and A. niger (Akpinar et al. 2017).

\section{Conclusion}

The current work demonstrates an efficient and economical green approach for producing $\mathrm{SiO}_{2} \mathrm{NPs}$ from $\mathrm{SB}$ and CC. At 3, 6, and 9 days intervals, $\mathrm{SiO}_{2} \mathrm{NPs}$ doses of 100 , 250, 500, and $1000 \mu \mathrm{g} \mathrm{L}^{-1}$ were administered. $\mathrm{SiO}_{2} \mathrm{NPs}$ applied to $E$. sativa seedlings improved not only plant biometrics and physiology, but also served as an antifungal agent. $\mathrm{SiO}_{2} \mathrm{NPs}$ inhibited $F$. oxysporum and A. niger with maximal inhibition percentages of 73.42 and 58.92, respectively. Many processes, such as plant interaction 


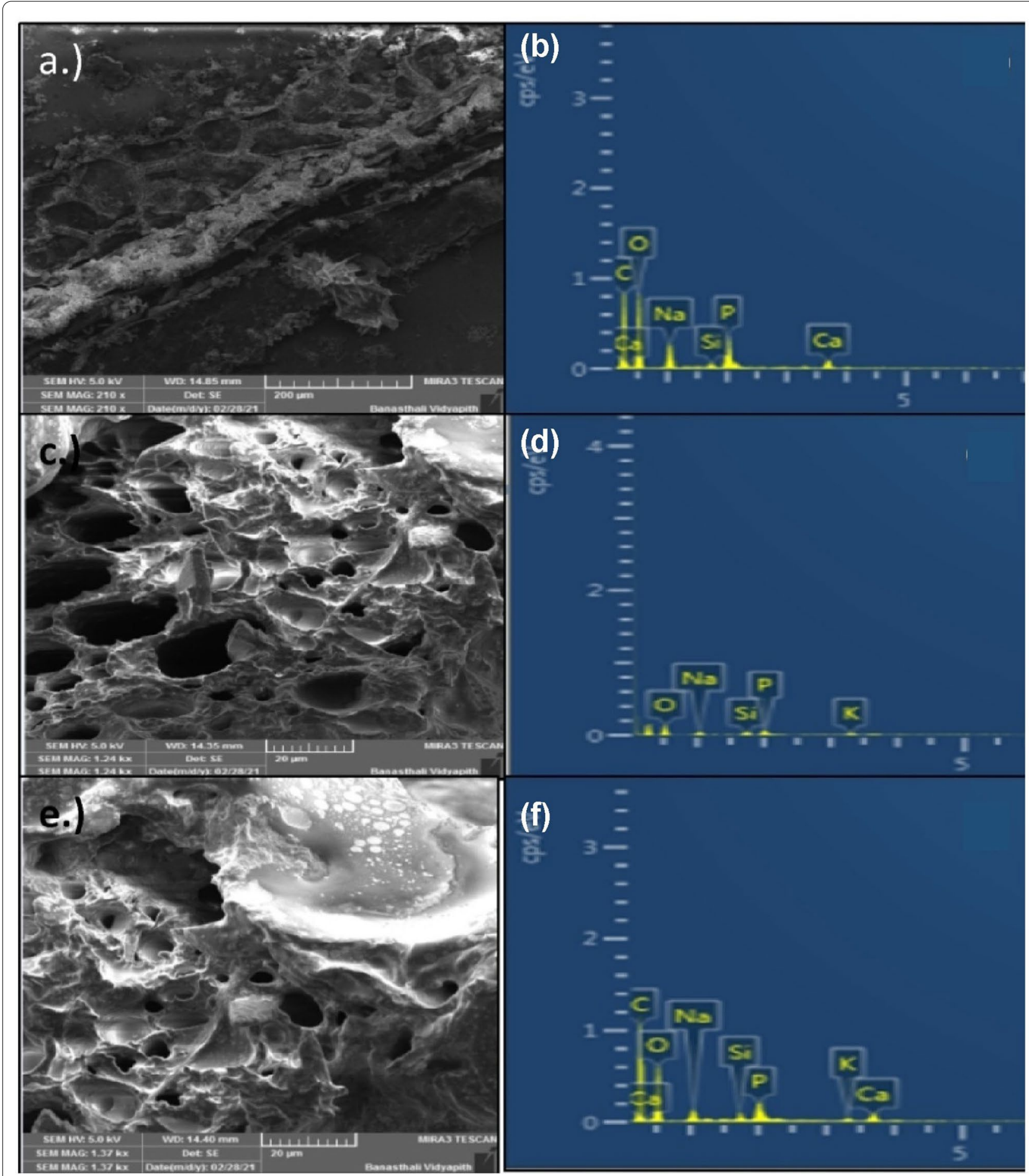

Fig. 7 a and $\mathbf{b}$ shows the FESEM and EDX spectrum of leaf tissues, $\mathbf{c}$ and $\mathbf{d}$ shoot tissue and $\mathbf{e}$ and $\mathbf{f}$ root tissues of E. sativa seedling at $1000 \mu \mathrm{g} \mathrm{L}^{-1}$ $\mathrm{SiO}_{2}$ NPs treatment after 9 days 
Table 1 Percentage (\%) of growth inhibition of F. oxysporum and A. niger by $\mathrm{SiO}_{2} \mathrm{NPs}$

\begin{tabular}{|c|c|c|c|c|c|c|}
\hline \multirow[t]{2}{*}{ Fungus } & \multicolumn{6}{|c|}{$\mathrm{SiO}_{2} \mathrm{NPs}$ content } \\
\hline & $1000 \mu \mathrm{g}$ & $500 \mu \mathrm{g}$ & $250 \mu g$ & $100 \mu g$ & Standard & Control \\
\hline Fusarium oxysporum & $73.42 \pm 1.14$ & $64.28 \pm 2.30$ & $61.30 \pm 1.69$ & $53.1 \pm 1.52$ & $M(97.67 \pm 0.0 \mathrm{M})$ & $0.00 \pm 0.00$ \\
\hline Aspergillus niger & $58.92 \pm 3.49$ & $51.1 \pm 2.79$ & $43.7 \pm 1.90$ & $41.5 \pm 1.58$ & $F(100)$ & $0.00 \pm 0.00$ \\
\hline
\end{tabular}

Each value represented in table are means $\pm S D(N=3), 0.00$ : indicates no inhibition

M, Manocozeb

with $\mathrm{SiO}_{2} \mathrm{NPs}$ and their cellular and molecular activities, necessitate further extensive investigation on all of these concerns. As a result, $\mathrm{SiO}_{2}$ NPs might be useful in agriculture sectors as fungicides and fertilizers.

\section{Abbreviations}

$\mathrm{SiO}_{2} \mathrm{NPS}$ : Silica nanoparticles; SEM: Scanning electron microscope; FTIR: Fourier transmission infrared spectroscopy; XRD: X-ray diffraction; EDX: Energy dispersive X-ray; SBA: Sugarcane bagasse; MIC: Minimum inhibitory concentration.

\section{Acknowledgements}

The authors are thankful to Prof. Ina Shastri (Vice-Chancellor) and Prof. Dipjyoti Chakraborty, Head of the Department, Bioscience and Biotechnology, Banasthali Vidyapith for their encouragement and assistance. We also thank the Bioinformatics Center, Banasthali Vidyapith, which is financed by DBT in India, for providing computational assistance.

\section{Authors' contributions}

$J M$ and PG conceived the present idea of writing the research and designed the content. JM encouraged to investigate and supervised the findings of this work. PG developed the theory and performed the experiments. JM and PG contributed to the analysis of the results and writing of the manuscript. Both authors read and approved the final manuscript.

\section{Funding}

The authors do not have any funding support.

\section{Availability of data and materials}

All data generated or analyzed during this study are included in this article.

\section{Declarations}

\section{Ethics approval and consent to participate}

Not applicable.

\section{Consent for publication}

The authors have consent for publication.

\section{Competing interests}

The authors declare that they have no competing interests.

Received: 17 August 2021 Accepted: 15 January 2022

Published online: 31 January 2022

\section{References}

Akpinar I, Sar T, Unal M (2017) Antifungal effects of silicon dioxide nanoparticles $\left(\mathrm{SiO}_{2} \mathrm{NPs}\right.$ ) against various plant pathogenic fungi. In: International workshop plant health: challenges and solutions

Alsaeedi AH, Elgarawany MM, El-Ramady H, Alshaal T, AL-Otaibi AOA (2019) Application of silica nanoparticles induces seed germination and growth of cucumber (Cucumis sativus). JKAU Met Env Arid Land Agric Sci 28(1):57-68
Aoudou Y, Tatsadjieu NL, Mbofung CM (2011) Mycelia growth inhibition of some Aspergillus and Fusarium species by essential oils and their potential use as antiradical agent. Agric Biol J N Am 2:1362-1367

Attia EA, Elhawat N (2021) Combined foliar and soil application of silica nanoparticles enhances the growth, flowering period and flower characteristics of marigold (Tagetes erecta L.). Sci Hortic 282:110015

Basha S, Ulaganathan K (2002) Antagonism of Bacillus species (strain BC121) towards Curvularia lunata. Curr Sci 25:1457-1463

Bradford MM (1976) A rapid and sensitive method for the quantitation of microgram quantities of protein utilizing the principle of protein-dye binding. Anal Biochem 72(1-2):248-254

Bray HG, Thorpe WV (1954) Analysis of phenolic compounds of interest in metabolism. Methods Biochem Anal. https://doi.org/10.1002/97804 70110171.ch2

Chan S, Don M (2012) Characterization of Ag nanoparticles produced by white-rot fungi and its in vitro antimicrobial activities. Int Arab J Antimicrob Agents 2(3: 3):1-8

Chanadee T, Chaiyarat S (2016) Preparation and characterization of low cost silica powder from sweet corn cobs (Zea maize saccharata L.). J Mater Environ Sci 7(7):2369-2374

Czerwińska E, Szparaga A (2015) Antibacterial and antifungal activity of plant extracts. Rocz Ochr Środowiska 17(1):209-229

Debona D, Rodrigues FA, Datnoff LE (2017) Silicon's role in abiotic and biotic plant stresses. Annu Rev Phytopathol 55:85-107

Derbalah A, Shenashen M, Hamza A, Mohamed A, El Safty S (2018) Antifungal activity of fabricated mesoporous silica nanoparticles against early blight of tomato. Egypt J Basic Appl Sci 5(2):145-150

Dhabalia D, Ukkund SJ, Syed UT, Uddin W, Kabir MA (2020) Antifungal activity of biosynthesized silver nanoparticles from Candida albicans on the strain lacking the CNP41 gene. Mater Res Express 7(12):125401

El-Serafy RS (2019) Silica nanoparticles enhances physio-biochemical characters and postharvest quality of Rosa hybrida L. cut flowers. J Hortic Res. https://doi.org/10.2478/johr-2019-0006

Gao X, Zou C, Wang L, Zhang F (2006) Silicon decreases transpiration rate and conductance from stomata of maize plants. J Plant Nutr 29:1637-1647

Güneş A, Kordali \$̧, Turan M, Bozhüyük AU (2019) Determination of antioxidant enzyme activity and phenolic contents of some species of the Asteraceae family from medicinal plants. Ind Crops Prod 137:208-213

Hafez EM, Osman HS, Gowayed SM, Okasha SA, Omara AED, Sami R, Usama A (2021) Minimizing the adversely impacts of water deficit and soil salinity on maize growth and productivity in response to the application of plant growth-promoting rhizo bacteria and silica nanoparticles. Agronomy 11(4):676

Kaya C, Tuna L, Higgs D (2006) Effect of silicon on plant growth and mineral nutrition of maize grown under water stress conditions. J Plant Nutr 29:1469-1480

Kumari S, Khan S (2017) Defluoridation technology for drinking water and tea by green synthesized $\mathrm{Fe}_{3} \mathrm{O}_{4} / \mathrm{Al}_{2} \mathrm{O}_{3}$ nanoparticles coated polyurethane foams for rural communities. Sci Rep 7(1):1-12

Kumari S, Khan S (2018) Effect of $\mathrm{Fe}_{3} \mathrm{O}_{4}$ NPs application on fluoride (F) accumulation efficiency of Prosopis juliflora. Ecotoxicol Environ Saf 166:419-426

Li WB, Shi XH, Wang H, Zhang FS (2004) Effects of silicon on rice leaves resistance to ultraviolet-B. Acta Bot Sin 46(6):691-697

Li J, Hu J, Ma C, Wang Y, Wu C, Huang J, Xing B (2016) Uptake, translocation and physiological effects of magnetic iron oxide $\left(\mathrm{Y}-\mathrm{Fe}_{2} \mathrm{O}_{3}\right)$ nanoparticles in corn (Zea mays L.). Chemosphere 159:326-334 
Ma JF, Yamaji N (2008) Functions and transport of Si in plants. Cell Mol Life Sci 65:3049-3057

Mostofa MG, Rahman MM, Ansary MMU, Keya SS, Abdelrahman M, Miah MG, Phan Tran LS (2021) Silicon in mitigation of abiotic stress-induced oxidative damage in plants. Crit Rev Biotechnol. https://doi.org/10.1080/07388 551.2021.1892582

Nair R, Poulose AC, Nagaoka Y, Yoshida Y, Maekawa T, Kumar DS (2011) Uptake of FITC labeled silica nanoparticles and quantum dots by rice seedlings: effects on seed germination and their potential as biolabels for plants. J Fluoresc 21(6):2057-2068

Palanivelu R, Padmanaban P, Sutha S, Rajendran V (2014) Inexpensive approach for production of high-surface-area silica nanoparticles from rice hulls biomass. IET Nanobiotechnol 8(4):290-294

Reynolds OL, Keeping MG, Meyer JH (2009) Silicon-augmented resistance of plants to herbivorous insects: a review. Ann Appl Biol 155(2):171-186

Sarangi M, Nayak P, Tiwari TN (2011) Effect of temperature on nano-crystalline silica and carbon composites obtained from rice-husk ash. Compos B Eng 42(7):1994-2199

Sethy NK, Arif Z, Mishra PK, Kumar P (2019) Synthesis of $\mathrm{SiO}_{2}$ nanoparticle from bamboo leaf and its incorporation in PDMS membrane to enhance its separation properties. J Polym Eng 39(7):679-687

Shah R, Kathad H, Sheth R, Sheth N (2010) In vitro antioxidant activity of roots of Tephrosia purpurea Linn. Int J Pharm Pharm Sci 2(3):30-33

Siddiqui MH, Al-Whaibi MH (2014) Role of nano-SiO ${ }_{2}$ in germination of tomato (Lycopersicum esculentum seeds Mill.). Saudi J Biol Sci 21(1):13-17

Singh TP, Bhatnagar J, Majumder CB (2015) Defluoridation of industrial wastewater using Eichhornia crassipes. Int I Sci Eng Technol 3:753-756

Sun D, Hussain HI, Yi Z, Rookes JE, Kong L, Cahill DM (2016) Mesoporous silica nanoparticles enhance seedling growth and photosynthesis in wheat and lupin. Chemosphere 152:81-91

Suriyaprabha R, Karunakaran G, Yuvakkumar R, Rajendran V, Kannan N (2012) Silica nanoparticles for increased silica availability in maize (Zea mays. L) seeds under hydroponic conditions. Curr Nanosci 8(6):902-908

Tubana BS, Babu T, Datnoff LE (2016) A review of silicon in soils and plants and its role in US agriculture: history and future perspectives. Soil Sci 181(9/10):393-411

Yew YP, Shameli K, Miyake M, Kuwano N, Khairudin NBBA, Mohamad SEB, Lee KX (2016) Green synthesis of magnetite $\left(\mathrm{Fe}_{3} \mathrm{O}_{4}\right)$ nanoparticles using seaweed (Kappaphycus alvarezii) extract. Nanoscale Res Lett 11(1):1-7

\section{Publisher's Note}

Springer Nature remains neutral with regard to jurisdictional claims in published maps and institutional affiliations.

\section{Submit your manuscript to a SpringerOpen ${ }^{\circ}$ journal and benefit from:}

- Convenient online submission

- Rigorous peer review

- Open access: articles freely available online

- High visibility within the field

- Retaining the copyright to your article

Submit your next manuscript at $\boldsymbol{\nabla}$ springeropen.com 